\title{
FINANCING OF BRAZILIAN COMPANIES DURING FINANCIAL CRISES: COMPARATIVE BETWEEN THE CRISES OF 2002, 2008 AND 2015
}

\author{
TATIANE D. A. FRANZOTTI ${ }^{1}$ \\ (iD) https://orcid.org/0000-0001-9602-6229 \\ VINÍCIUS M. MAGNANI \\ https://orcid.org/0000-0002-0069-954X \\ MARCELO A. AMBROZINI ${ }^{1}$ \\ (iD) https://orcid.org/0000-0003-0933-6064 \\ MAURÍCIO R. VALLE ${ }^{1}$ \\ (iD) https://orcid.org/0000-0003-2439-3526
}

To cite this paper: Franzotti, T. D. A., Magnani, V. M., Ambrozini, M. A., \& Valle, M. R., (2021). Financing of Brazilian companies during financial crises: Comparative between the crises of 2002, 2008 and 2015. Revista de Administração Mackenzie, 22(1), 1-35. doi:10.1590/1678-6971/ eRAMF210154

Submission: Sept. 1st, 2019. Acceptance: May 26, 2020.

1 University of São Paulo (USP), Ribeirão Preto, SP, Brazil.

2 Moura Lacerda University Center (CUML), Ribeirão Preto, SP, Brazil.

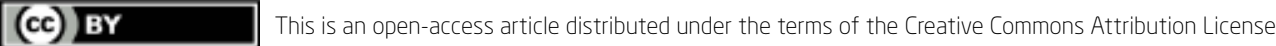

\footnotetext{
This paper may be copied, distributed, displayed, transmitted or adapted for any purpose, even commercially, if provided, in a clear and explicit way, the name of the journal, the edition, the year and the pages on which the paper was originally published, but not suggesting that RAM endorses paper reuse. This licensing term should be made explicit in cases of reuse or distribution to third parties.

Este artigo pode ser copiado, distribuído, exibido, transmitido ou adaptado para qualquer fim, mesmo que comercial, desde que citados, de forma clara e explícita, o nome da revista, a edição, o ano e as páginas nas quais o artigo foi publicado originalmente, mas sem sugerir que a RAM endosse a reutilização do artigo. Esse termo de licenciamento deve ser explicitado para os casos de reutilização ou distribuição para terceiros.
} 


\section{ABSTRACT}

Purpose: The purpose of this study is to verify the financing decisions by Brazilian companies in the financial crises of 2002, 2008 and 2015, and to identify the impacts of these crises, as well as the influence of the funding sources - banking, subsidized sources and capital markets - on the leverage and maturity of companies' debts in these periods.

Originality/value: Crises establish opportunities for the study of determining factors and their impacts on companies. There is no empirical evidence on the impacts of crises on the capital structure of Brazilian companies taking into account the comparison between the crises of 2002, 2008 and 2015, which motivated the present study.

Design/methodology/approach: We performed descriptive analyzes and estimated regressions by panel data.

Findings: The results showed a statistically positive relationship between financial crises and corporate leverage, as well as short and long-term debt. With regard to leverage, banking resources, resources from capital and subsidized markets showed a statistically positive relationship with the level of leverage of companies only in the 2008 crisis. Considering the maturity of debts, the 2002 crisis was an important determinant for companies' short-term debt decisions, in view of the predominant participation of banking resources at that time. Financing sources were important in determining companies' long-term indebtedness in the 2008 crisis.

\section{KEYWORDS}

Capital structure. Financial crises. Credit market. Funding sources. Leverage. 


\section{INTRODUCTION}

Considered the theoretical framework of the modern finance theory, the 1958 study by Modigliani and Miller led from then on to raise several studies and arguments involving the capital structure of companies, which consists of the combination of resources that finance them. Such studies include, among other factors, market imperfections (Jensen \& Meckling, 1976; Myers \& Majluf, 1984; Myers, 1984) and institutional and macroeconomic factors (Booth, Aivazian, Demirguc-Kunt, \& Maksimovicet al., 2001). Additionally, most studies focus on the demand for resources, represented by the attributes of companies, as the main determinants of the capital structure. However, Faulkender and Petersen (2006) reinforce the importance of observing the supply of resources in determining the capital structure of companies.

Especially since the 2008 subprime crisis, there is an intensification of interest in studying the impacts of financial crises on the capital structure of companies. Some of them point to an increase in corporate leverage in times of crisis, as in Fosberg (2012) and Alves and Francisco (2015), often explained by stock market disruptions. On the other hand, authors like Akbar, Rehman, and Ormrod (2013) observed an increase in the share of shares during the crisis, due to shocks in bank credit. Regarding debt maturity, evidence shows an increase in short-term debt by companies during financial crises, greater aversion to bank risk and rising long-term debt costs (Fosberg, 2012; Alves \& Francisco, 2015).

Speaking of Brazil, in particular, which is the country studied in this research, some characteristics surround the context of the credit offered to companies. Sant'Anna, Rodrigues, and Araujo (2009) and Paula, Oreiro, and Basilio et al.(2013) highlight the participation of the Brazilian Development Bank (Banco Nacional de Desenvolvimento Econômico e Social BNDES), in which long-term financing and subsidized rates predominate in times of financial crisis. According to the authors, the bank acts in a compensatory manner in relation to the rest of the financial system, increasing its disbursements in times of crisis, when bank financing becomes undermined. That said, Lima, Assaf Neto, Perera, and Silva et al.(2011) highlighted the increase in corporate debt in the 2008 crisis, whereas Carvalhal and Leal (2013) and Silva, Santos, Perobelli, and Nakamura (2016) showed evidence of the increased share of long-term debt in the crisis.

In this sense, three relevant financial crises have marked the Brazilian context since the beginning of the 2000s, which occurred in the years 2002, 2008 and 2015 . At the end of 2002, instabilities were motivated by the drop 
in liquidity in the international capital market and by factors in Brazil, and also by the uncertainties related to the presidential election period. According to data from the Central Bank, between the months of January and September 2002, the dollar (USD) rate, in reais (BRL) per dollar, rose by approximately $70 \%$, and ended the year with a $12.5 \%$ inflation. The 2008 crisis started with the subprime crisis in the United States, affecting the confidence of the financial system worldwide. That year, industrial production, for example, fell by $20 \%$, according to information from Valor Econômico. More recently, since 2015, political and economic instabilities have been occurring in Brazil, impacting the credit supply, affecting the financial conditions of companies and causing gross domestic product (GDP) to drop by 6\% compared to 2014 .

Faced with the evidence of the impact of financial shocks on the capital structure, it is observed that, to date, there is no empirical evidence about the impacts of financial crises on the capital structure of Brazilian companies taking into account the comparison between the crises of 2002, 2008 and 2015, since they occurred at different times and contexts. With this gap identified, the question we investigated in this research can be enunciated:

- What are the impacts of financial crises on the capital structure of Brazilian companies considering the crises of 2002, 2008 and 2015?

Thus, the objective of this study is to compare the decisions about the capital structure of Brazilian companies in the crises of 2002, 2008 and 2015, analyzing the impacts of these crises, as well as the influence of financing sources, on the leverage and maturity of companies' debts in these periods.

The present study contributes with a view of the capital structure of Brazilian companies in the financial crises that impacted the Brazilian economy, providing evidence that may be important in the way companies and financial markets view the role of sources of funds, such as BNDES and capital markets in mitigating problems related to shocks in the supply of resources. Still, in addition to the determinants normally used in empirical studies to explain capital structure, such as tangibility, profitability, size and growth opportunities, the study advances in the inclusion of financing sources used in times of financial and economic instability, providing evidence of how crises can affect the economy in different ways, and may depend on the development of credit markets at any given time.

\section{LITERATURE REVIEW}

Modigliani and Miller (1958) are researchers widely recognized for initiating a strong discussion on the role of financing decisions in the man- 
agement of companies. By adopting assumptions such as the existence of perfect markets, the absence of information asymmetry and bankruptcy costs, and the possibility that individuals and firms can apply and borrow at the risk-free rate, the authors initially maintained the absence of an optimal capital structure capable of maximizing the firm's value, attributing the ability to generate wealth to corporate investment decisions. However, the authors themselves, in a 1963 article, reassessed the effects of income tax on legal entities, a tax already present in the 1958 article, and started to consider the impact of the capital structure, due to the tax benefit, on the company's value.

From these two studies, a long discussion and academic production took place, initially with a focus on the tax benefits of the debt, and, afterwards, incorporating costs resulting also from indebtedness, such as the costs of financial difficulties probably present in higher levels of financial leverage. Subsequently, informational asymmetries and agency conflicts also came to be among the factors capable of influencing capital structure decisions and financing preferences. This set of factors, then, ended up being consolidated or giving rise to some theoretical approach, such as the trade-off (Kraus \& Litzenberger, 1973; Myers, 1984), the pecking order (Myers, 1984; Myers \& Majluf, 1984) and the market timing (Baker \& Wurgler, 2002).

Furthermore, Faulkender and Petersen (2006) give relevance to the importance of access and supply of resources used by companies as a factor considered in debt decisions, and not only the variables related to the attributes of the firm traditionally used in these studies.

In order to verify the effects of the 2008 financial crisis on the capital structure of companies, Fosberg (2012) empirically shows that the debt/ equity ratio increased from 2007 to 2008, with an increase in the share of debts in the capital structure of companies during the height of the crisis, falling again in 2009. The author attributes the increase in the share of debts in relation to shares to the rupture in the capital market.

Fosberg (2012) portrayed an increase in short-term debt in the capital structure of companies in the 2008 crisis caused by the reduction of financing offered and a decline in long-term debt and equity financing. According to the author, the increase in short-term debt in the crisis was reversed in 2009, suggesting that a shorter debt maturity would be unwanted by companies.

In seeking to assess the impact of financial crises on corporate financing decisions and on how institutional variables influenced such decisions, Alves and Francisco (2015) evaluated three crises: the internet bubble, the subprime crisis and the European sovereign debt crisis. By analyzing the period of 2000-2011, the authors found evidence that indicates an increase 
in leverage and in the level of short-term debt during crises, indicating that cumulative financial crises create conditions of stress for companies, where companies' financial risks are greater. The authors argue that the evidence of substituting long-term debt for short-term debt in times of crisis is explained by the greater information asymmetry during these shocks, the drop in credit supply and the increase in long-term debt issuance costs.

When looking for evidence of the effects of the 2008 crisis on the capital structure of companies, Borges, Ambrozini, and Rodrigues (2018) concluded that there were statistically significant changes in the capital structure of companies between the periods before and after the crisis. A reduction in the leverage levels of all analyzed groups was pointed out, and the crisis had similar effects among companies in developed and developing countries.

In bringing some evidence in the Brazilian context, some characteristics of the Brazilian credit market were described by Sant'Anna et al. (2009) and Paula et al. (2013), highlighting the role of the BNDES, especially in times of crisis. By investigating changes in the bank credit market between 2004 and 2008, Sant'Anna et al. et al.(2009) point out that there was a considerable expansion of credit by national and foreign public and private banks in the period. The authors showed that, as of September 2008, with the fall of the Lehman Brothers, private banks maintained the level of credit operations practically stable, while public banks, especially the BNDES, accelerated the expansion of the supply of resources. According to the authors, BNDES acts in a compensatory manner vis-à-vis the rest of the financial system.

At times when the market contracts, as in the 2001-2003 period, the Bank increases its participation in guaranteeing access to credit for companies in times of scarce liquidity. However, when the credit market expands, BNDES sees its participation reduce, leaving the private sector to meet the demand for credit (Sant'Anna et al., 2009, p. 53).

Likewise, Paula et al. (2013) highlighted the increase, from the 2008 financial crisis, in disbursements by BNDES for long-term financing, especially considering the strong retraction in the market for private corporate bonds (shares and debentures). In this sense, in times of economic instability, banks seek to reduce risks, shortening the average maturity of loans and financing, reducing the supply of long-term credit. However, the greater participation of BNDES, influenced by government policies in these periods, would lead to a greater participation of long-term financing.

Lima et al. (2011) studied the relationship between economic indicators, such as inflation, exchange rate and interest rate, and the capital structure 
of Brazilian companies in times of financial crises. With data from 1995 to 2007, the authors found evidence that the exchange rate significantly affects companies' indebtedness, while the interest rate affects it less significantly. The authors found that, in times of instability, companies increase their indebtedness, mainly due to the greater sensitivity of the debt to exchange rate variables.

Carvalhal and Leal (2013) investigated the determinants of the capital structure of Brazilian companies before and after the 2008 financial crisis. According to the authors, the effects of the 2008 crisis on Brazilian companies resulted in a fall in short-term debt, particularly bank debts, although the companies' capital structure has remained stable. The authors explain that large companies started to replace short-term financing with long-term financing, mainly through capital markets, in addition to using greater domestic financing in the year of the crisis.

When studying the role of financing sources on the capital structure of Brazilian companies between the years 2005-2012, Tarantin and Valle (2015) evidenced the increase in the capital market share of companies, and the crisis variable was not significant in relation to leverage when considering book values. Likewise, with regard to maturity, the authors pointed out that the crisis of financial institutions did not cause changes in the maturity of corporate debts.

By analyzing the impacts of the 2008 financial crisis on the capital structure of companies from BRIC (Brazil, Russia, India and China), Silva et al. (2016) observed different intensities of the effects of the crisis in the four countries. Companies in Brazil, Russia and China showed considerable growth in long-term debt during the crisis period, while in India more mature debt fell.

When investigating the impacts of financial crises in 2008 and 2015 on investments and on the financing of constrained and unconstrained Brazilian companies, Franzotti and Valle (2020) obtained evidence that only the 2008 crisis had a greater and negative impact on the leverage of constrained companies, in addition to an increase in the proportion of short-term debt mainly for this group of companies. In the study, the 2015 crisis negatively impacted only corporate investments, mainly from constrained companies.

When analyzing the influence of the crisis that occurred between 2014 and 2016 in Brazil, as well as macroeconomic variables, on corporate debt, Cardoso and Pinheiro (2020) pointed out that the Brazilian recession was relevant to explain the capital structure of companies, and the inflation variable was only relevant for the health sector. In addition, company-specific 
variables, such as profitability, showed greater relevance in determining the capital structure when compared to macroeconomic variables.

In summary, in view of the studies and evidence presented, the present study, in addition to raising comparisons between the crises of 2002, 2008 and 2015, seeks evidence about the impacts of crises on corporate leverage. There are divergent results in the literature regarding the relationship between crises and leverage. While Lima et al. (2011), Fosberg (2012) and Alves and Francisco (2015) point to a statistically positive relationship between crises and leverage, explained, among other factors, by the increase in informational asymmetry and participation of foreign currency debts, Borges et al. (2018) and Franzotti and Valle (2020) obtained a negative relationship, reflecting possible shocks in the supply of resources.

With regard to the maturity of corporate debts, authors such as Fosberg (2012), Alves and Francisco (2015) and Franzotti and Valle (2020) point to an increase in short-term debt in times of crisis, reflecting the risk aversion of banks, which shorten the maturity of their loans. On the other hand, Sant'anna et al. (2009), Paula et al. (2013) and Silva et al. (2016) observed an increase in long-term debt, which may reflect the role of subsidized credits offsetting the drop in funds made available to companies. In this study, the segregation of subsidized resources in econometric models was included precisely to test this hypothesis of the long-term compensatory role of sources such as the BNDES.

Finally, in line with Faulkender and Petersen (2006) and Tarantin and Valle (2015), analyzes of companies' sources of financing were included to test the hypothesis that they are important factors in determining companies' capital structure.

\section{RESEARCH METHOD}

The method adopted in this study seeks to meet the objective of comparing decisions about the capital structure of Brazilian companies in the crises of 2002, 2008 and 2015, as well as investigating the level of leverage and debt maturity, emphasizing the influence of financing sources on capital structure decisions.

We estimated regressions by panel data. According to Cardoso and Pinheiro (2020), who studied the impacts of crises on corporate indebtedness, panel data assumes that the values of the variables and their relationships are constant over time and across the sample units, with an advantage: the 
reduction of multicollinearity problems and the impact of omitted variables. In this sense, Fávero (2015) discusses some steps of estimating regressions with panel data, one of which being the choice between the fixed effects model and the random effects model, being made based on the Hausman test. In this study, estimations were made using robust clustered standard errors. In the Hausman test, the significance level of $1 \%$ was considered.

\subsection{Sample}

The sample from this study is composed of 55 Brazilian non-financial companies, between 2001 and 2015, comprising the three financial crises in question. At first, to define the sample, we selected, through the software Economatica ${ }^{\circledR}$, the 100 largest companies according to asset size in 2014, the year before the last crisis. Of the initial companies, 38 were excluded due to active non-registration in the Securities and Exchange Commission of Brazil (Comissão de Valores Mobiliários - CVM), and 7 companies were not included in the final sample due to the lack of necessary and reliable information.

\subsection{Variables}

Financing sources were segregated into bank credits, capital (debentures) and subsidized debts (lines of credit mainly from BNDES, whose rates are lower than market rates), through data collection in explanatory notes on loans and financing throughout the period, annually. In the same way, debt maturity information was collected, separated in short (up to one year) or long term. Data related to the firm's leverage and attributes - tangibility, profitability, size, and market-to-book - were collected using the Economatica ${ }^{\circledR}$ software.

\subsubsection{Dependent variables}

We built three analyzes with different dependent variables. To capture the capital structure, the ratio total debts/total assets was used, as in Carvalhal and Leal (2013), Alves and Francisco (2015), Tarantin and Valle (2015), Franzotti and Valle (2020), and Cardoso and Pinheiro (2020).

The other two analyzes aim to analyze the debt maturity. For this purpose, as in Carvalhal and Leal (2013), short-term debts (short-term debts/total assets) and long-term debts (long-term debts/total assets) were segregated. 


\subsubsection{Independent variables}

For the definition of periods of crisis, the periods of greatest uncertainty in the Brazilian economy were adopted, according to the Brazilian Economy Uncertainty Indicator, by the Brazilian Institute of Economics (Instituto Brasileiro de Economia - IBRE). In summary, the index seeks to measure the uncertainty of the Brazilian economy from information collected from the country's main newspapers, the Ibovespa Index and financial market expectations about macroeconomic variables. According to information from the IBRE Blog (2018), some of the periods of uncertainty in the Brazilian economy were the electoral period of 2002, the 2008/09 international financial crisis and the second half of 2015 . Thus, the crisis variables used in this study were defined:

- 2002 crisis: dummy with value 1 in 2002;

- 2008 crisis: dummy with value 1 in 2008 and 2009;

- 2015 crisis: dummy with value 1 in 2015.

To point out the determinants of the capital structure of companies with regard to sources of financing in times of crisis, as in Tarantin and Valle (2015), we use the proportions of bank, subsidized and capital market debt over total debt, collected from the financial statements from 2001 to 2015, and classified according to the following criteria:

- Bank debts: from private and public banks, except BNDES and other development banks.

- Subsidized debts: involve loans and financing, mainly from BNDES, whose interest rates are lower than market rates, such as Brazil's long term interest rate.

- Capital markets: mainly involve financing by debentures.

\subsubsection{Control variables}

The control variables used in this study are represented by characteristics of the companies traditionally pointed out in the capital structure literature, linked to the demand for debt. The construction of these variables is based on Frank and Goyal (2009), Carvalhal and Leal (2013), Alves and Francisco (2015), Tarantin and Valle (2015), Silva et al. (2016), Franzotti and Valle (2020), and Cardoso and Pinheiro (2020). They are:

- Tangibility: total fixed assets/total assets: The literature suggests that tangibility is important, since it can play the role of collateral to third 
parties, as in Silva et al. (2016). Therefore, in this case, a positive relationship between tangibility and leverage is expected. On the other hand, the issue of shares may become less costly when associated with the low informational asymmetry of tangible assets, as pointed out by Frank and Goyal (2009), leading to a negative relationship between the variables.

- Profitability: earnings before interest, taxes, depreciation and amortzation (Ebitda)/total asset: According to Silva et al. (2016), the relationship between profitability and leverage can have different interpretations. The relationship can be positive, since with a higher profitability, the costs of bankruptcy are lower and, therefore, the debt benefits increase. On the other hand, it may show a negative relationship, as more profitable companies may prefer internal financing to external financing (shares and debt).

- Size: In (total assets): The variable size of companies can also have different interpretations in relation to leverage. For Silva et al. (2016), the relationship can be positive in the sense that larger companies are more diversified and with low risk of default, becoming more indebted. However, the relationship can also be negative, since larger companies face fewer problems of adverse selection and can issue more shares.

- Market-to-book: market value of assets/book value of assets: This variable represents the company's growth opportunities. Silva et al. (2016) point out that there may be a positive relationship between growth opportunities and leverage, since greater opportunities require greater indebtedness. However, Tarantin and Valle (2015) note that a negative relationship means that firms with greater growth opportunities are financed predominantly by stocks, avoiding agency problems.

Figure 3.2.3.1 summarizes the variables and their constructions.

(Figure 3.2.3.1)

SYNTHESIS OF VARIABLES

\begin{tabular}{lll}
\hline \multicolumn{1}{c}{ Variables } & \multicolumn{1}{c}{ Proxy } & \multicolumn{1}{c}{ Authors } \\
\hline Dependent variables & & \\
\hline Indebtedness & Total debts/total assets & Alves and Francisco (2015), Tarantin and \\
(debt/asset) & & Valle (2015), Silva et al. (2016), Franzotti \\
& & and Valle (2020), Cardoso and Pinheiro \\
& $(2020)$. \\
\hline
\end{tabular}




\section{(Figure 3.2.3.1 (conclusion))}

SYNTHESIS OF VARIABLES

\begin{tabular}{|c|c|c|}
\hline Variables & Proxy & Authors \\
\hline \multicolumn{3}{|l|}{ Dependent variables } \\
\hline Short-term debts & Short-term debts/total assets & Carvalhal and Leal (2013) \\
\hline Long-term debts & Long-term debts/total assets & Carvalhal and Leal (2013) \\
\hline \multicolumn{3}{|l|}{ Independent variables } \\
\hline $\begin{array}{l}\text { Crisis } \\
2002 \text { crisis } \\
2008 \text { crisis } \\
2015 \text { crisis }\end{array}$ & $\begin{array}{l}\text { Dummy } 1 \text { for crisis and } 0 \text { for } \\
\text { other periods }\end{array}$ & $\begin{array}{l}\text { Alves and Francisco (2015), Tarantin and } \\
\text { Valle (2015), and Silva et al. (2016) }\end{array}$ \\
\hline Bank credits & Ratio of bank debt to total debt & Tarantin and Valle (2015) \\
\hline Subsidized credits & $\begin{array}{l}\text { Proportion of subsidized debt } \\
\text { over total debt }\end{array}$ & Tarantin and Valle (2015) \\
\hline $\begin{array}{l}\text { Capital markets } \\
\text { credits }\end{array}$ & $\begin{array}{l}\text { Proportion of credits from } \\
\text { capital markets on total debt }\end{array}$ & Tarantin and Valle (2015) \\
\hline \multicolumn{3}{|l|}{ Control variable } \\
\hline Tangibility & Total fixed assets/total assets & $\begin{array}{l}\text { Frank and Goyal (2009), Carvalhal and } \\
\text { Leal (2013), Alves and Francisco (2015), } \\
\text { Tarantin and Valle (2015), Silva et al. } \\
\text { (2016), and Franzotti and Valle (2020) }\end{array}$ \\
\hline Profitability & Ebitda/total assets & $\begin{array}{l}\text { Frank and Goyal (2009), Carvalhal and } \\
\text { Leal (2013), Alves and Francisco (2015), } \\
\text { Tarantin and Valle (2015), Silva et al. } \\
\text { (2016), and Franzotti and Valle (2020) }\end{array}$ \\
\hline Size & In(total assets) & $\begin{array}{l}\text { Frank and Goyal (2009), Carvalhal and } \\
\text { Leal (2013), Alves and Francisco (2015), } \\
\text { Tarantin and Valle (2015), Silva et al. } \\
\text { (2016), and Franzotti and Valle (2020) }\end{array}$ \\
\hline $\begin{array}{l}\text { Market-to-book } \\
\text { (growth opportunities) }\end{array}$ & $\begin{array}{l}\text { Market value of assets/book } \\
\text { value of assets }\end{array}$ & $\begin{array}{l}\text { Frank and Goyal (2009), Carvalhal and } \\
\text { Leal (2013), Alves and Francisco (2015), } \\
\text { Tarantin and Valle (2015), Silva et al. } \\
\text { (2016), and Franzotti and Valle (2020) }\end{array}$ \\
\hline
\end{tabular}

Source: Elaborated by the authors. 


\subsubsection{Empirical models}

The general model of the study is as follows, for each company $i$ and year $t$ :

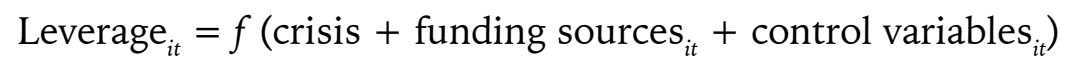

Four models were adopted, both for debt and debt maturity, in order to analyze the impacts of crises and sources of financing on the capital structure of companies. The first model has the idea of investigating each of the three crises studied separately, without considering the sources of financing:

$$
\begin{gathered}
\text { Leverage }=2002 \text { crisis }+2008 \text { crisis }+2015 \text { crisis }+ \\
\text { tangibility }+ \text { profitability }+ \text { size }+\mathrm{M} / \mathrm{B}
\end{gathered}
$$

In the second model, even without considering the sources of financing, crises are considered in general, without segregating each one of them:

$$
\text { Leverage }=\text { financial crisis }+ \text { tangibility }+ \text { profitability }+ \text { size }+\mathrm{M} / \mathrm{B}
$$

In the third model, the sources of financing are included, in such a way that interactions are made between each crisis with each source, in order to statistically analyze the impacts of each financing source in each crisis on the leverage of companies:

Leverage $=2002$ crisis +2008 crisis +2015 crisis + tangibility + profitability + size $+\mathrm{M} / \mathrm{B}+$ capital credits + capital credits $* 2002$ crisis + capital credits*2008 crisis + capital credits*2015 crisis +

bank credits + bank credits*2002 crisis + bank credits*2008

crisis + bank credits $* 2015$ crisis + subsidized credits + subsidized credits*2002 crisis + subsidized credits* 2008 crisis + subsidized credits*2015 crisis

Finally, in the fourth model, we follow the same intuition as the third model, with the difference that all crises are considered together:

Leverage $=$ financial crisis + tangibility + profitability + size + $\mathrm{M} / \mathrm{B}+$ capital credits + capital credits* crisis + bank credits + bank credits* ${ }^{*}$ crisis + subsidized credits + subsidized credits* ${ }^{*}$ crisis 


\section{RESULTS AND DISCUSSIONS}

Figure 4.1 shows the descriptive statistics regarding leverage, debt maturity and the debt profile of companies in the period from 2001 to 2015.

\section{(Figure 4.1)}

DESCRIPTIVE STATISTICS

\begin{tabular}{lcrrccc}
\hline & Debts/TA & $\begin{array}{r}\text { Debts } \\
\text { ST/TA }\end{array}$ & $\begin{array}{r}\text { Debts } \\
\text { LT/TA }\end{array}$ & $\begin{array}{c}\text { Bank } \\
\text { credits }\end{array}$ & $\begin{array}{c}\text { Capital market } \\
\text { credits }\end{array}$ & $\begin{array}{c}\text { Subsidized } \\
\text { credits }\end{array}$ \\
\hline Mean & $32.4 \%$ & $8.8 \%$ & $23.5 \%$ & $33.8 \%$ & $31.9 \%$ & $30.2 \%$ \\
\hline Median & $32.6 \%$ & $6.7 \%$ & $23.4 \%$ & $29.9 \%$ & $31.8 \%$ & $23.3 \%$ \\
\hline Maximum & $99.4 \%$ & $43.7 \%$ & $91.5 \%$ & $100.0 \%$ & $99.0 \%$ & $100.0 \%$ \\
\hline Minimum & $0.0 \%$ & $0.0 \%$ & $0.0 \%$ & $0.0 \%$ & $0.0 \%$ & $0.0 \%$ \\
\hline Standard deviation & $15.3 \%$ & $7.4 \%$ & $13.6 \%$ & $23.8 \%$ & $25.4 \%$ & $24.3 \%$ \\
\hline Observations & 814 & 814 & 814 & 814 & 814 & 814 \\
\hline
\end{tabular}

Debts/TA - total debts/total assets; debts ST/TA - short-term debts/total assets; debts LT/TA - long-term debts/ total assets.

It is noted that, in relation to leverage, debts represent almost $33 \%$ of the total assets, on average. As for maturity, on average, long-term debt predominates over short-term debt, which can be explained by the significant presence of debentures and subsidized debts, mainly from the BNDES, whose characteristics are essentially linked to interest rates below market rates, as well as long-term maturity. It is worth mentioning that the financing sources do not add up to $100 \%$ of the debts, since the resources classified as "lease" and "other", which represent a tiny portion compared to other sources.

Figure 4.2 presents the descriptive statistics of the control variables.

(Figure 4.2)

DESCRIPTIVE STATISTICS CONTROL VARIABLES

\begin{tabular}{lcccc}
\hline & M/B & Size & Profitability & Tangibility \\
\hline Mean & 2.12 & 15.20 & 0.14 & 0.37 \\
\hline Median & 0.62 & 15.25 & 0.13 & 0.37 \\
\hline
\end{tabular}




\section{(Figure 4.2 (conclusion))}

DESCRIPTIVE STATISTICS CONTROL VARIABLES

\begin{tabular}{lcccc}
\hline & M/B & Size & Profitability & Tangibility \\
\hline Maximum & 80.64 & 18.62 & 0.50 & 0.91 \\
\hline Minimum & 0.00 & 1.14 & -0.13 & 0.00 \\
\hline Standard deviation & 9.06 & 1.82 & 0.08 & 0.25 \\
\hline Observations & 814 & 812 & 814 & 814 \\
\hline
\end{tabular}

M/B - market-to-book, calculated at market value of assets/book value of assets; size - total logarithm of total assets; profitability - Ebitda/total assets; tangibility - total fixed assets/total assets.

\section{Source: Elaborated by the authors.}

Regarding the variables that represent characteristics of the companies, we point out that the average size of companies, 15.20, is close to the maximum of all companies, 18.62, which indicates that, in fact, the companies in the sample are mostly large. In addition, the number of observations for this variable is lower (812) in relation to the other variables due to the unavailability of information in two periods of the same company in the sample.

Authors such as Lima et al. (2011), Fosberg (2012) and Alves and Francisco (2015) showed that companies increased leverage in times of crisis. The graphic analysis (Figure 4.3), which considers the evolution of the leverage of the companies in the sample of this study in the period, measured by the ratio of debt to total assets, shows the leaps in companies' leverage in the three mentioned moments of crisis. According to Alves and Francisco (2015), these increases would be explained by the accentuation of informational asymmetries in crises, which, in turn, affect the capital markets, making investors in these markets more risk-averse. Lima et al. (2011), in turn, explain that, in times of instability and consequent increase in exchange rates, as occurred in the 2002 crisis, the indebtedness of companies that have debts linked to foreign currencies increases, due to the sensitivity of the debt to increases in the exchange rate. 


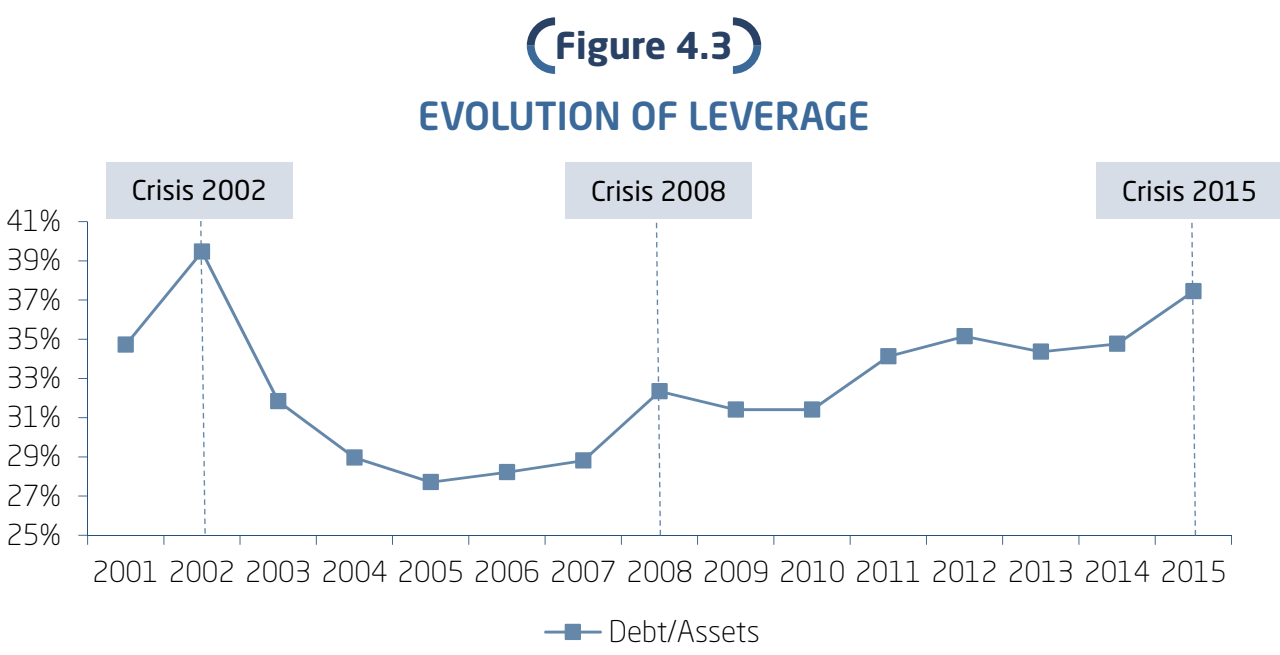

Source: Elaborated by the authors.

In view of the increases in corporate leverage in times of crisis, Figure 4.4 shows the evolution of financing sources, when considering bank debts, capital markets and subsidized debts.

\section{(Figure 4.4)}

\section{EVOLUTION OF FINANCING SOURCES}

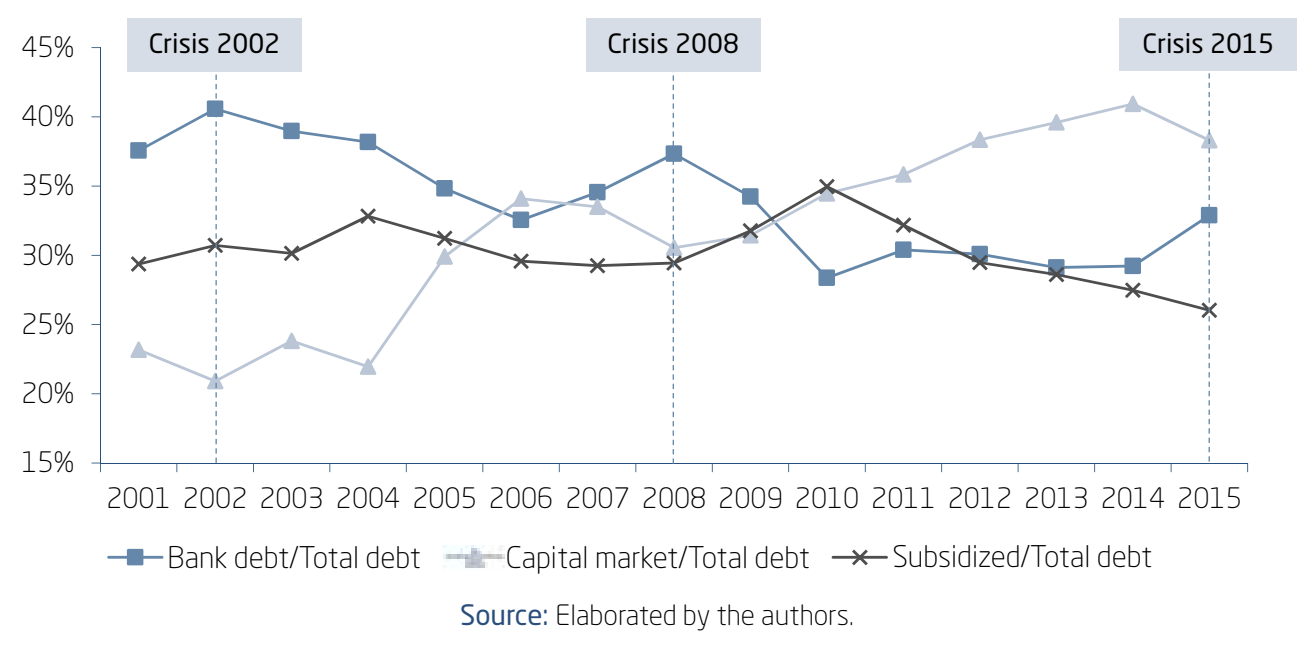

Figure 4.4 shows that, between 2001 and 2006, bank debts predominated over other sources in the composition of companies' total debts. As of 2006, debts in the capital markets have surpassed subsidized debts. As 
placed by Tarantin and Valle (2015), the upward movement of capital markets participation in the composition of Brazilian companies' indebtedness can be explained by the development of capital markets in Brazil in the period and by CVM Instruction n. 476 de 2009, enabling lower emission costs. As of 2011, financing from the capital markets started to predominate over other sources.

With regard to periods of crisis, it is noted that in the crises of 2002, 2008 and 2015 companies had an increase in the participation of bank debts, subsequently experiencing a fall. In relation to debt through the capital market, it is noted that, in the three moments of crisis, the share of this source in the total debts of companies is reduced. Paula et al. (2013) pointed to this strong retraction in the market for private corporate bonds (shares and debentures) in the 2008 crisis, also showing itself in this study, apparent in the 2002 and 2015 crises.

Finally, the movement of subsidized debts is different in the three moments of crisis. In the 2002 crisis, the share of subsidized debts increased in 2002 and mainly in 2004, when bank debts were reduced, as predicted by the BNDES' countercyclical role. In the 2008 crisis, the participation of subsidized sources was stable at first, increasing considerably in 2009 and 2010, in parallel with the drop in bank debts, playing, once again, a compensatory role. In the 2015 crisis, the share of subsidized resources, which had been declining, continued to fall, unlike the other periods of crisis under study. This difference in the role of the BNDES in the 2015 crisis can be explained, according to information from the Bank's 2015 Annual Report, for changes in its performance in the midst of this crisis, "making financing lines more expensive and resulting in a reduction in disbursed resources" (BNDES, 2016, p. 5). In addition, it is mentioned that the performance of the Bank's activities was questioned in that year by society and control bodies, influencing these changes.

Evidence points to an increase in short-term debt and a reduction in long-term debt in times of crisis, as in Paula et al. (2013), Fosberg (2012) and Alves and Francisco (2015). According to Paula et al. (2013), this movement occurs in times of instability as banks seek to reduce risks, shortening the average maturity of loans and financing, consequently decreasing the supply of long-term credit.

Figure 4.5 shows the evolution of the debt maturity of the companies in the sample of this study, highlighting the highest proportion of long-term debt in all periods. 


\section{(Figure 4.5) \\ DEBT MATURITY EVOLUTION}

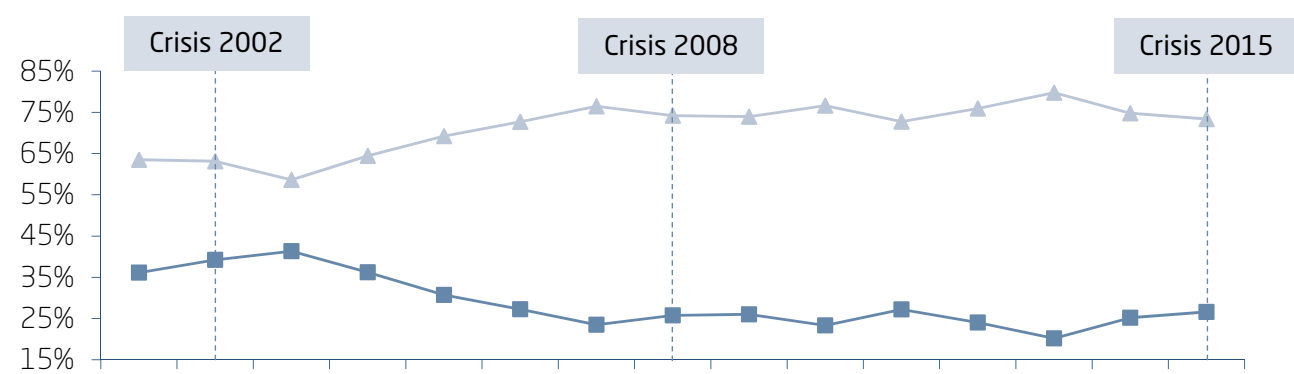

200120022003200420052006200720082009201020112012201320142015

$\rightarrow$-Short term debt/Total debt $\rightarrow \mathbf{m}$-Long term debt/Total debt

Source: Elaborated by the authors.

It is noted that, according to evidence in the literature, companies reduced their long-term debt and increased short-term debt in times of crisis. The greatest variation occurred in the 2008 crisis, in which long-term debt dropped from $77 \%$ in 2007 to $74 \%$ in 2008 , while short-term debt rose from $23 \%$ to $26 \%$ of the total debt. These movements accompany the increase in bank debt in these periods, which may justify the positive variation in shortterm debt.

From the descriptive analyzes developed so far, the following are the statistical analyzes, performed using the panel data methodology. Figure 4.6 shows the relationship between leverage and sources of financing in times of crisis.

The control variables tangibility and profitability were negative and significant in all models, and the market-to book variable proved to be negative and significant in model 4 . The negative relationship between the variable tangibility and leverage can indicate, according to Frank and Goyal (2009), that the issuing of shares becomes less costly when associated with the low informational asymmetry of tangible assets, presenting a negative relationship between these variables. In turn, the negative relationship between profitability and leverage can occur, since more profitable companies may prefer internal financing to external financing (stocks and debts), according to Silva et al. (2016). Finally, the negative relationship between growth opportunities (market-to book) and leverage, significant in the fourth model, indicates that firms with greater growth opportunities are financed predominantly by stocks, avoiding agency problems, as in Tarantin and Valle (2015). 


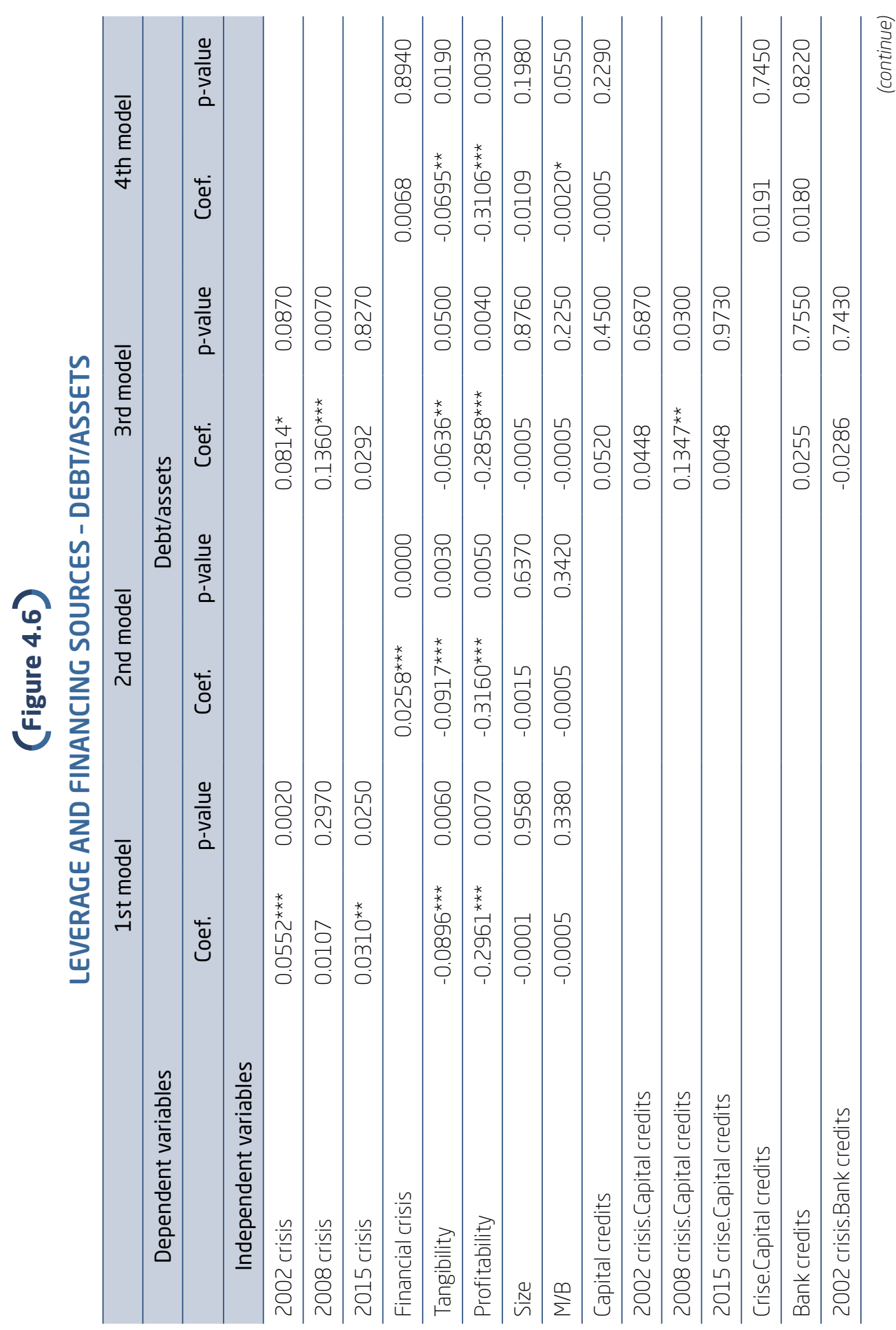




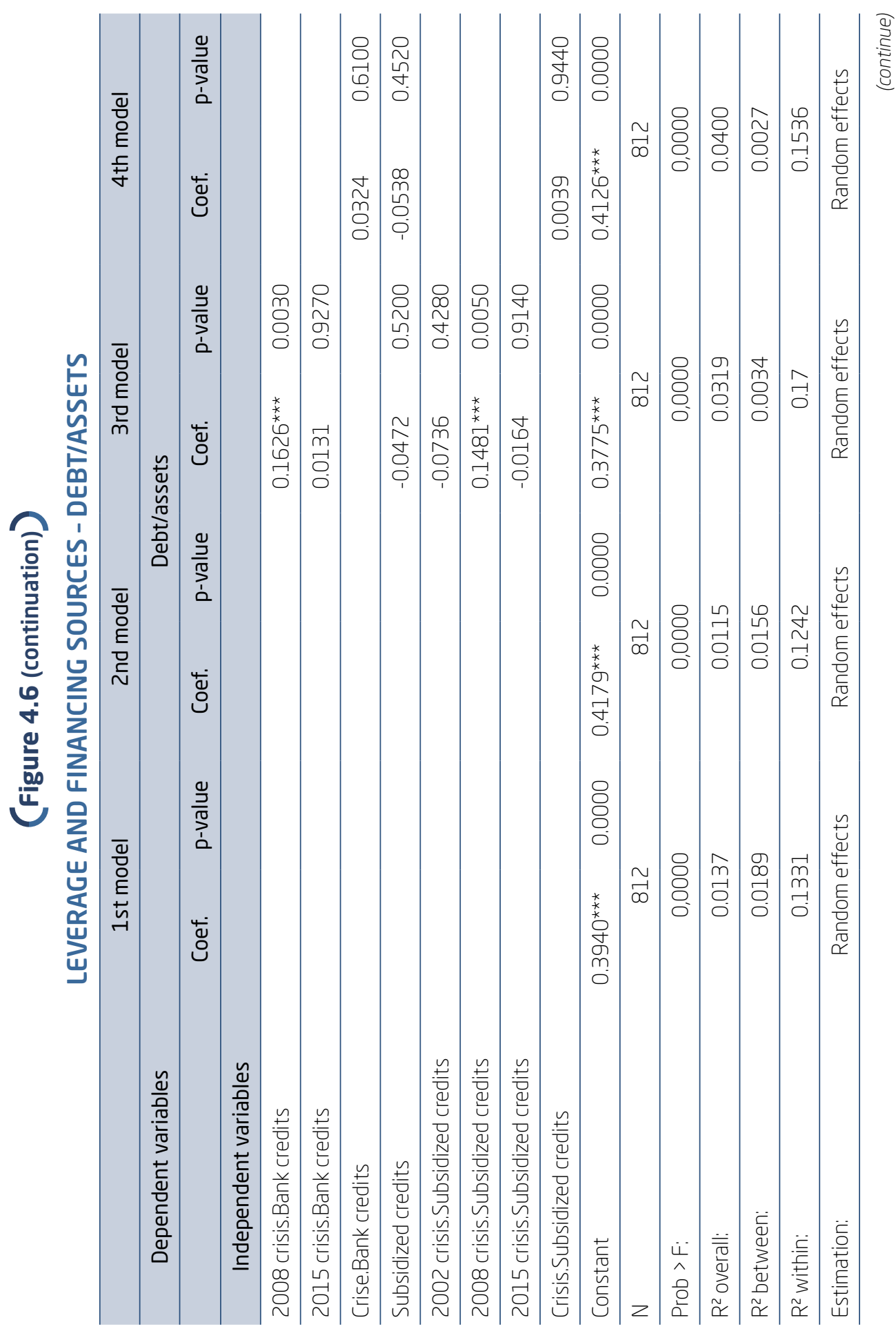




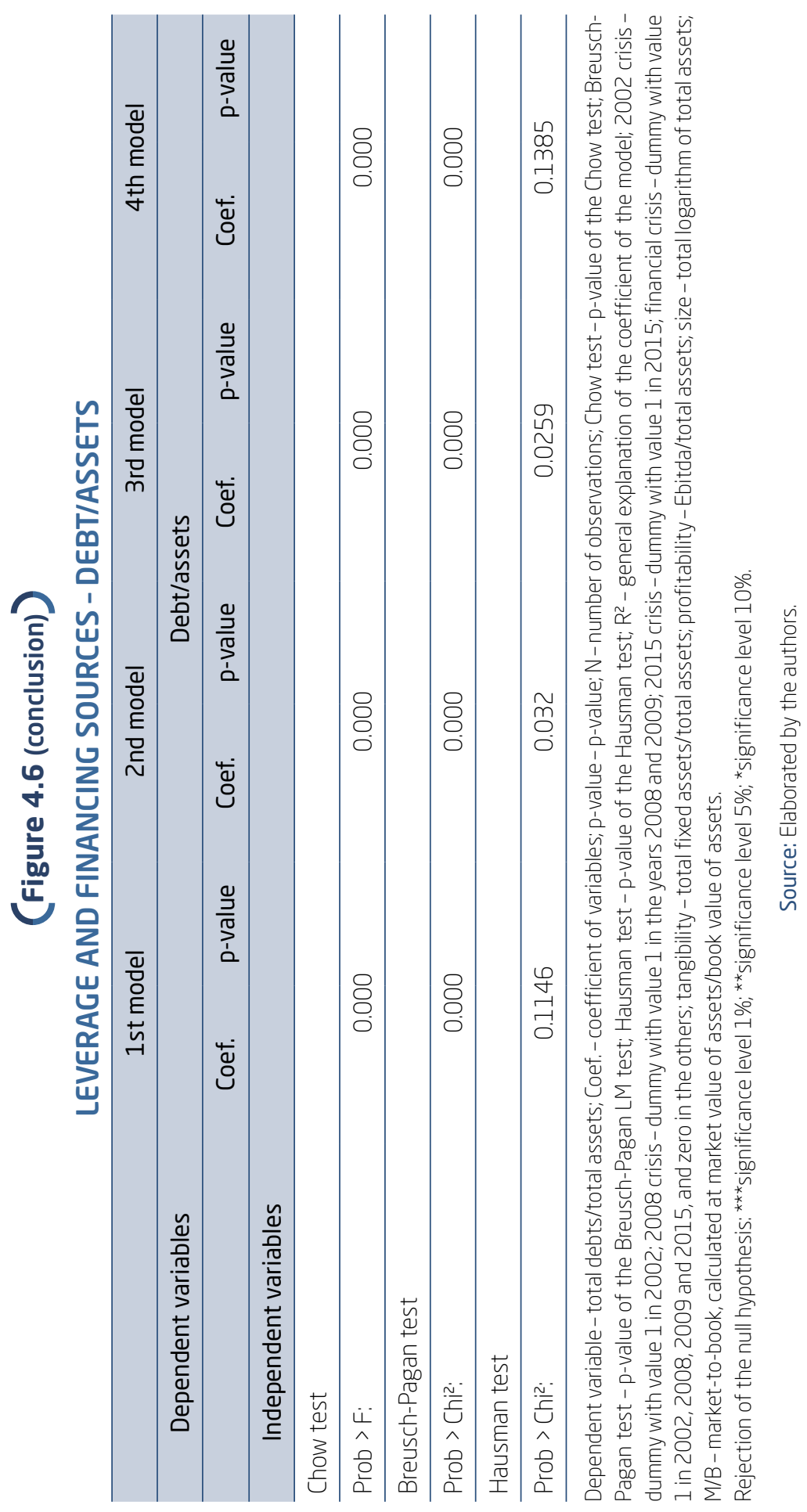


Considering the crises of 2002, 2008 and 2015 separately, in the first model, it is observed that only the crises of 2002 and 2015 are positive and significant with regard to leverage, which corroborates the descriptive view presented earlier that companies increased their indebtedness in these periods, as in Lima et al. (2011) and Alves and Francisco (2015), either because of the greater risk aversion of investors in the capital markets (Alves \& Francisco, 2015), or by the sensitivity of foreign currency debts by companies to increases in the exchange rate (Lima et al., 2011).

However, when the interactions of each of the crises with the sources of financing are made, in the third model, only the crises of 2002 and, mainly of 2008, are significant to explain the leverage. At the same time, all sources of financing were statistically positive and significant only in the 2008 crisis. Thus, it is possible to infer that, when financing sources are included in the study of the impact of crises on the leverage of companies, sources of banking, capital and subsidized resources contributed to companies' financing decisions in the 2008 crisis. The positive relationship between bank resources and leverage in the 2008 crisis, which considers the years 2008 and 2009, can be explained by the reflexes of the aforementioned expansion of the bank credit that occurred up to that period, as highlighted by Sant'Anna et al. (2009) and Paula et al. (2013), which reduced from then on. At the same time, the positive and statistically significant relationship between subsidized resources and leverage in the 2008 crisis confirms the compensatory role of BNDES at that time. Finally, the positive and significant relationship between capital market resources in the 2008 crisis and leverage may be demonstrating the influence of the development of capital markets in Brazil at that time, in addition to the CVM Instruction n. 476 de 2009, which led to increases in the issuance of debentures by companies.

Considering the effects of crises in general, analyzed together, there is a statistically positive and significant relationship between crises and leverage. However, the influence of financing sources on companies' leverage at these times is not observed, indicating that, in times of crisis in general, companies make their leverage decisions based on other more relevant factors, such as the firm's attributes. The results show that the characteristics of the companies, given by the variables of control, tangibility, profitability and growth opportunities, were important to explain the leverage of companies in times of crisis analyzed together, leaving aside factors linked to the supply of resources classified by source of financing. This may indicate that companies, when perceiving the crises, adapted their demands for financing to avoid future financial problems. According to Figure 4.3, this movement 
would be reflected in the drop in corporate debt immediately after the crises of 2002 and 2008.

Figures 4.7 and 4.8 , show the effects of crises and sources of financing on short and long-term debt, respectively.

Analyzing the crises of 2002, 2008 and 2015 separately, in the first model, only the crisis of 2002 proved to be significant, at $1 \%$, and positive to explain the short-term debts of companies. The increase in short-term debt during crises, as pointed out by Paula et al. (2013), Fosberg (2012) and Alves and Francisco (2015), indicates a greater risk aversion by banks and increased long-term debt costs. Since at that time, on average, companies were mostly financed by banks, as shown in Figure 4.4, the statistically positive impact of short-term debt on corporate leverage shows evidence of banks' reactions to the supply of funds with less maturity, as highlighted by Paula et al. (2013).

Despite the significance and positive relationship between bank credits and short-term debt throughout the period under analysis, from 2001 to 2015, as expected, there is no evidence of the influence of funding sources in the three crises on short-term debt.

In analyzing the impacts of crises in general, in the second model, it is concluded that financial crises in general have statistically positive impacts on companies' short-term debt, in line with previous studies. However, when funding sources are included in the fourth model, crises are no longer significant and funding sources were not considered to be decisive factors in these decisions.

The same analyzes were performed for long-term debt.

When analyzing the impacts of crises on long-term debt, in the first model, without considering the sources of financing, a statistically positive and significant impact, at $10 \%$, of the 2015 crisis on long-term indebtedness was observed, with the influence of the 2002 and 2008 crises being insignificant. Explanations for this impact were not found through the participation of financing sources, since none of them showed significance in this crisis. 


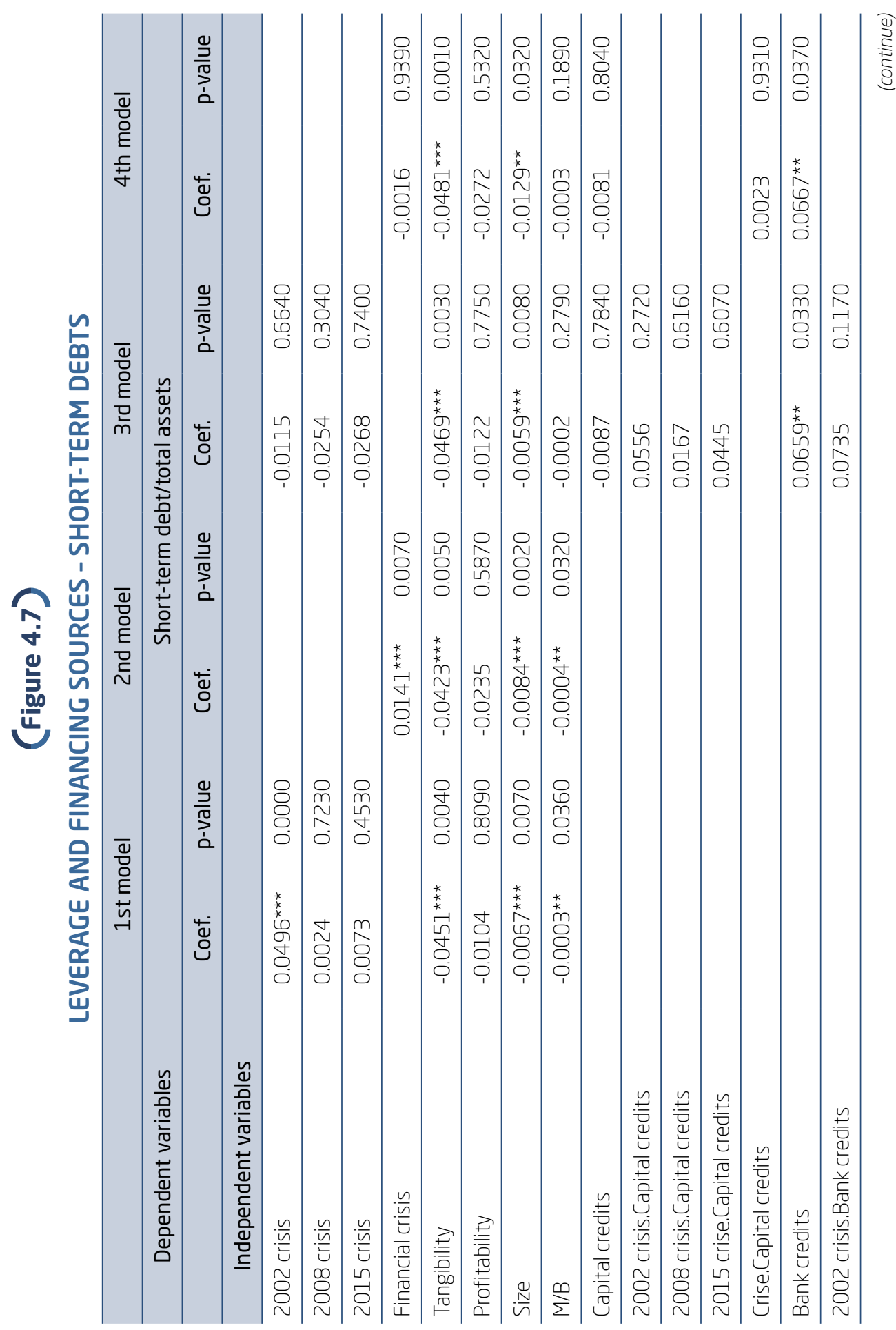




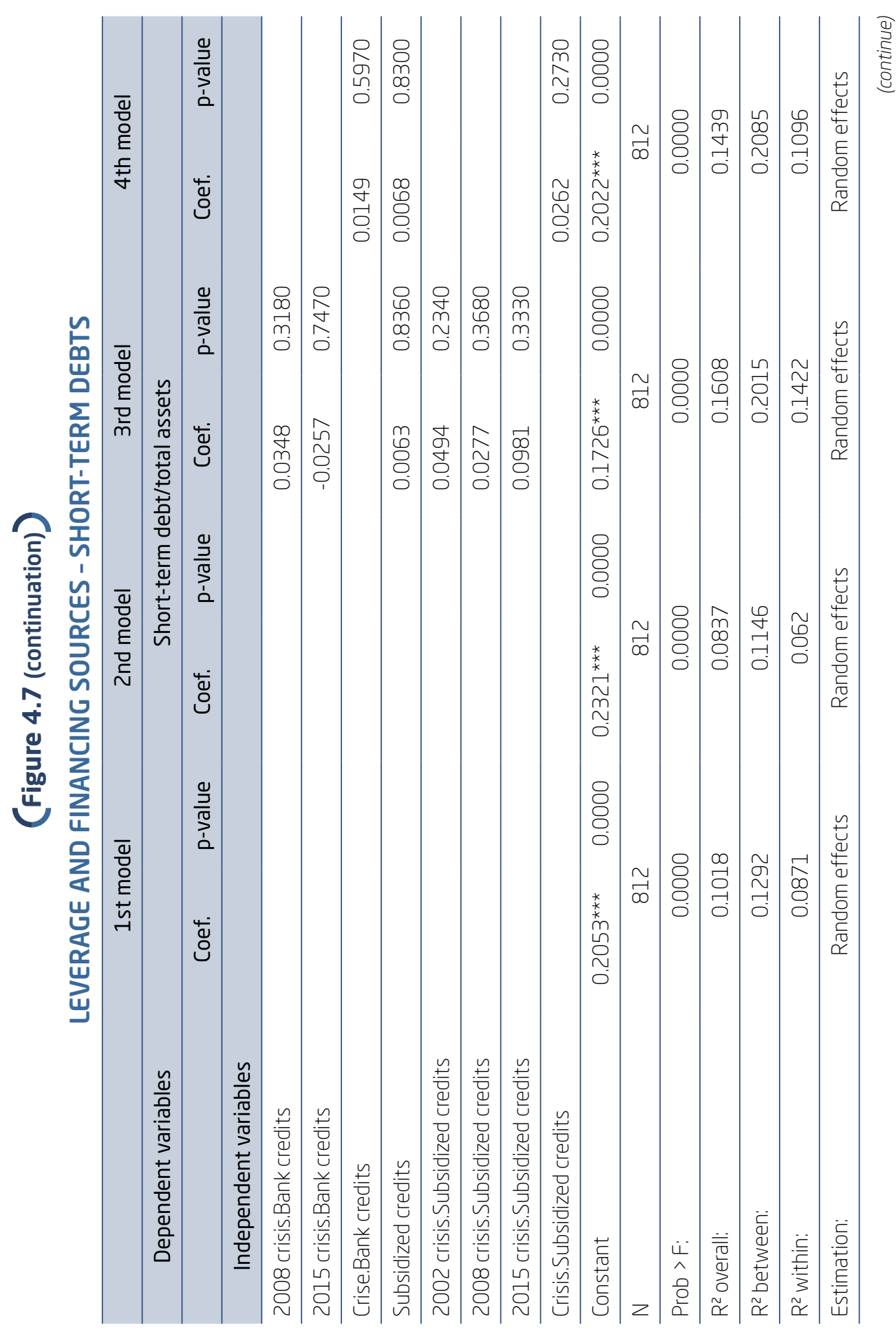




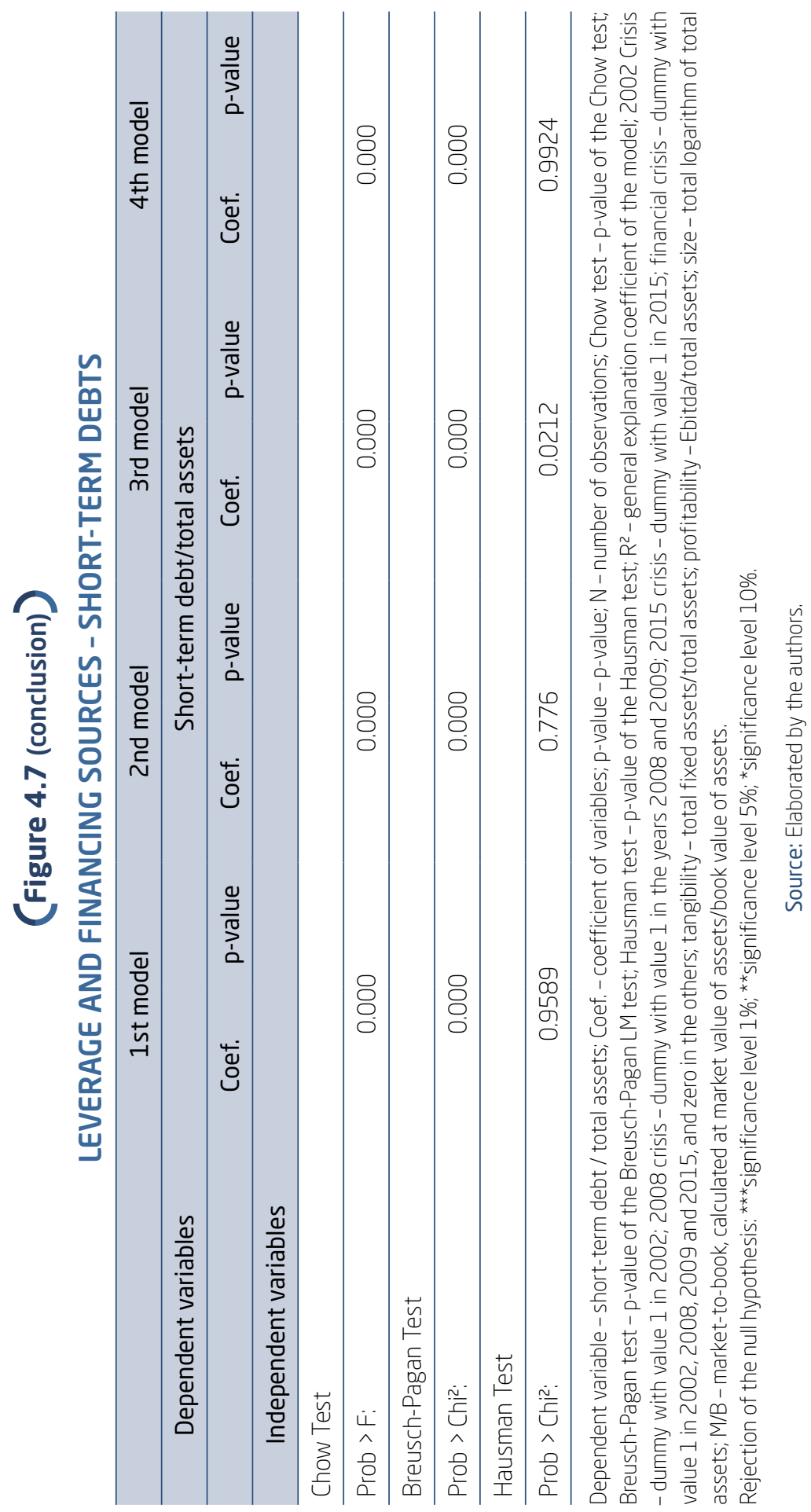




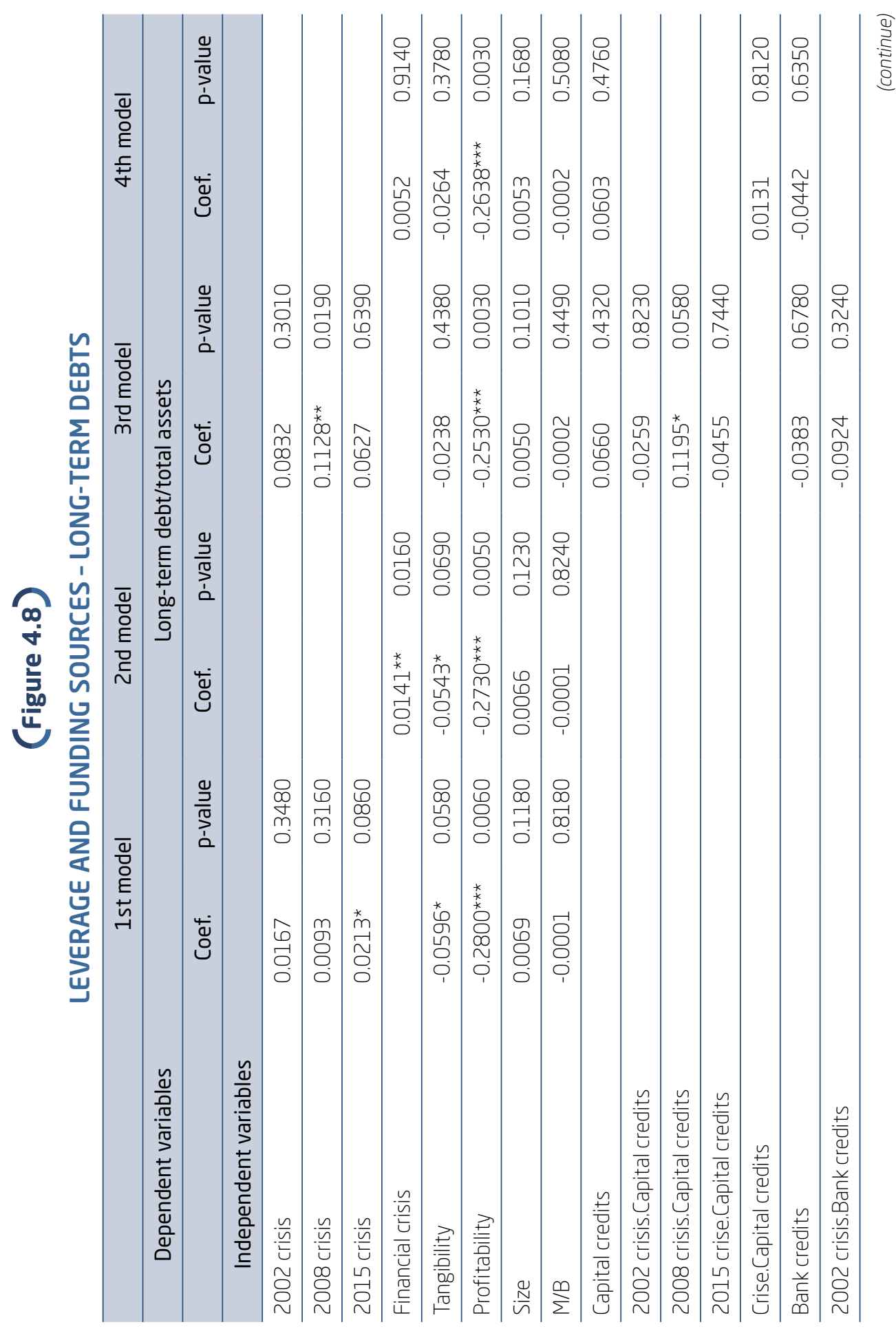




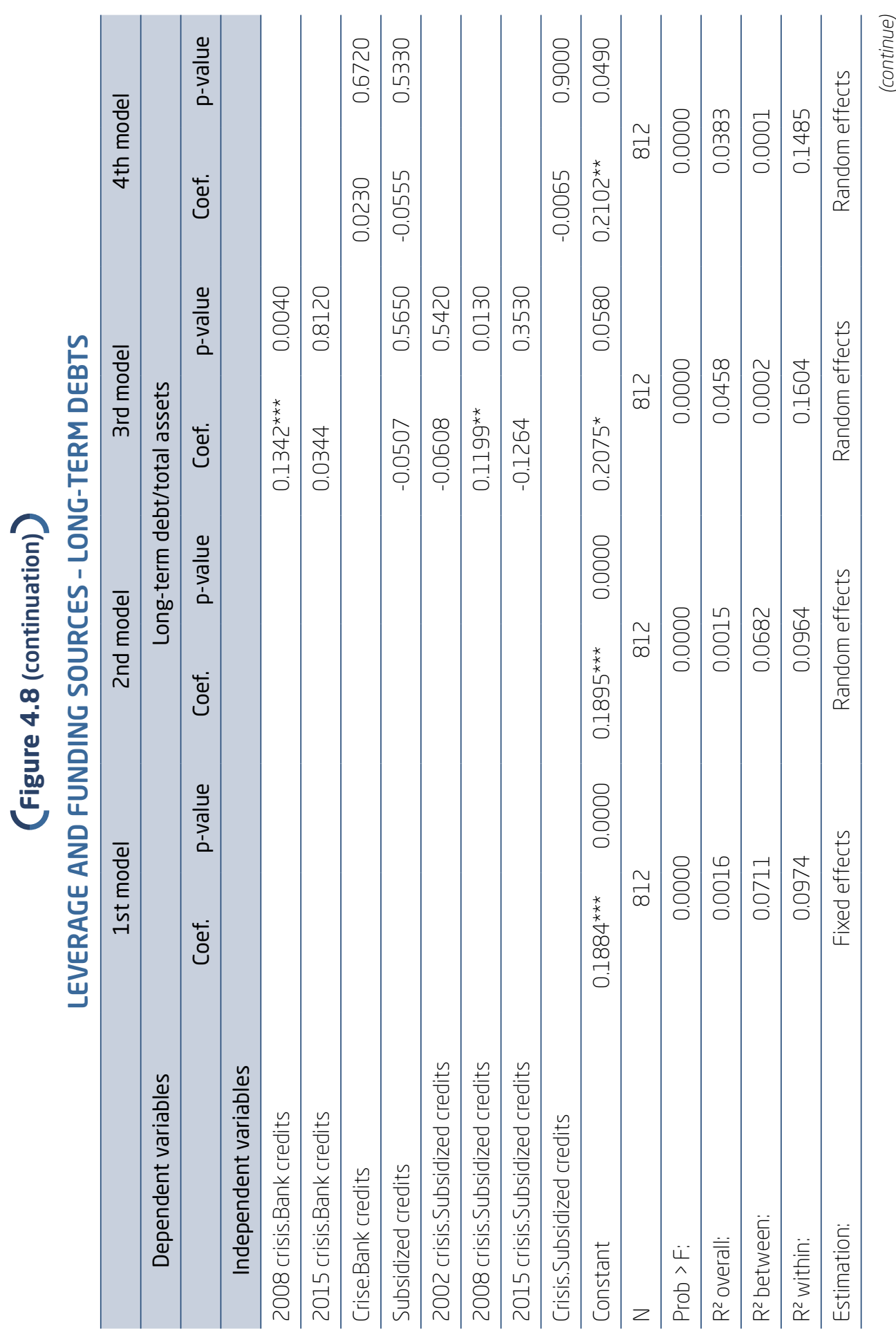




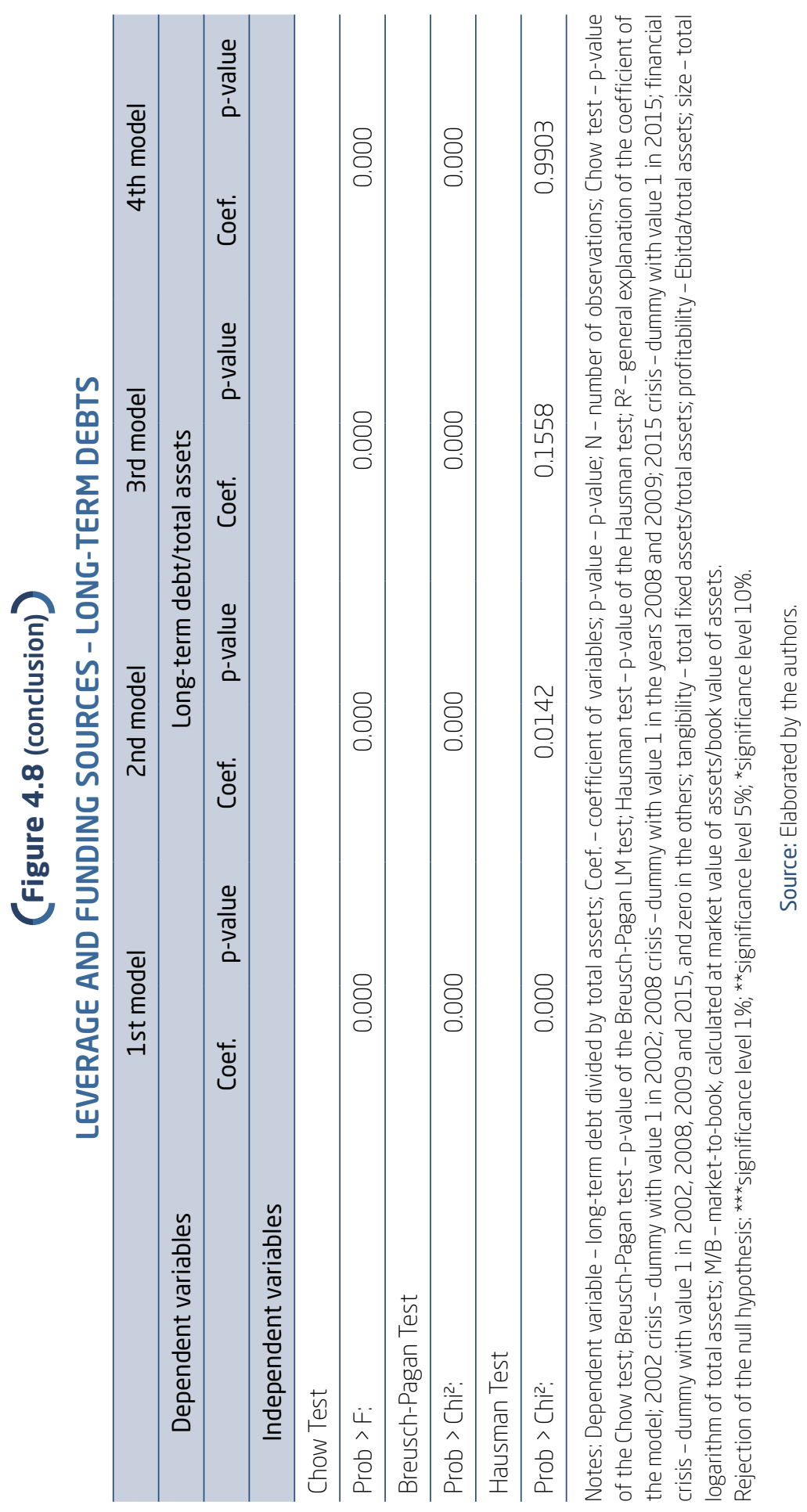


When the third model is analyzed, in which each of the crises is analyzed separately and with the inclusion of the sources of funds, the crisis of 2015 becomes statistically insignificant and, the 2008 crisis, significantly and statistically positive (positive relationship between crisis and long-term debt). Contrary to the insignificant influence of all sources on short-term debt in the 2008 crisis, some effects are observed when considering the sources of financing and the long-term debt of companies in this crisis. As in the analysis of the influence of financing sources in times of crisis on leverage, it is noted that, once again, financing sources were important in determining long-term debt only in the 2008 crisis. There is evidence of a statistically positive and significant relationship between bank debt and long-term debt in the 2008 crisis, which may be reflecting the expansion of bank credit up to that moment, possibly with greater maturity. In addition, there is a statistically positive and significant relationship between subsidized debt and long-term debt in the 2008 crisis, consistent with the BNDES's countercyclical performance at that time, as in Sant'Anna et al. (2009) and Paula et al. (2013). Likewise, capital markets resources also showed a statistically positive and significant relationship with long-term debt, reflecting the increased share of capital markets in the financial structure of companies and in the long-term maturity of debentures.

Financial crises in general, in the second model, showed a statistically positive and significant relationship to explain long-term debt, a relationship contrary to expectations. This relationship can be explained by the Brazilian peculiarities referring mainly to the presence of long-term subsidized resources by BNDES. However, once again, the sources of financing were not significant to explain these more mature debts, and crises in general become insignificant when sources are included.

In summary, the evidence in this study points to a statistically positive impact of financial crises on the leverage of companies, as in Lima et al. (2011), Fosberg (2012) and Alves and Francisco (2015). These impacts were more important in the 2002 and 2015 crises in Brazil, although the 2008 crisis was an important determinant when sources of financing were included. In the 2008 subprime crisis, banking, capital markets and subsidized sources were important in companies' leverage decisions, occurring in parallel with the development of the capital market and the strong performance of the government in granting credit. In addition, as noted in Figure 4.4, at that time, the participation of these sources of financing in the companies' balance sheets was narrowed, which can explain its influences on debt decisions. 
Considering the short-term maturity of debts, we note that only the 2002 crisis was an important determinant, justified by the greater bank participation at that time. However, the sources of financing were not relevant factors in determining the short-term debt of companies. On the other hand, considering long-term debt decisions, the influence of the 2015 crisis is observed and when considering the sources of financing of the 2008 crisis amid the countercyclical participation of the BNDES in 2008 and of the debentures in 2015, reflecting in a longer-term maturity of the debts. As noted for leverage, the three sources of financing were significant and positive in determining companies' long-term indebtedness in the 2008 crisis.

\section{FINAL CONSIDERATIONS}

The main objective of this study was to compare the decisions about the capital structure of Brazilian companies in the crises of 2002, 2008 and 2015, involving the level of leverage, debt maturity and the impacts of financing sources on companies' financing decisions. The three moments of crisis mark different moments in the Brazilian credit market, such as CVM Instruction n. 476 of 2009 and the BNDES' role in offering resources, which further motivates the search for understanding the impacts of the sources of financing included in the analyzes.

The results showed a statistically positive relationship between financial crises and corporate leverage, as well as between crises and debt maturity. However, the results are particular to each crisis in question. Financing sources proved to be more important on companies' debt decisions in the 2008 subprime crisis, possibly reflecting the context of defining the participation of credit markets at that time - development of capital markets, CVM Instruction n. 476/2009, compensatory performance of the BNDES and reflections of years of expansion of the bank credit in Brazil.

A statistically positive relationship was observed between bank resources, capital markets resources and subsidized resources with companies' leverage level only in the 2008 crisis. Furthermore, the 2002 crisis was an important determinant for companies' short-term debt decisions, given the predominant participation of banking resources at that time. Financing sources were important in determining companies' long-term indebtedness in the 2008 crisis.

There are some limitations in the current research. One is the selection of large companies only, to compose the sample of the study. This factor can cause bias in the analysis of the results. Another limitation is the use of annual, rather than quarterly, information to analyze the effects of crises on 
companies' capital structure, since they would bring a more informational content in the data.

As suggestions for future research, estimates using nonlinear techniques for estimating models can be interesting, in addition to checking the impacts of capital costs of each source of financing available to companies.

\section{FINANCIAMENTO DE EMPRESAS BRASILEIRAS DURANTE CRISES: COMPARATIVO ENTRE AS CRISES DE 2002, 2008 E 2015}

\section{RESUMO}

Objetivo: O objetivo deste trabalho foi verificar as decisões de financiamento pelas empresas brasileiras nas crises financeiras de 2002, 2008 e 2015, e identificar os impactos dessas crises, assim como a influência das fontes de financiamento - fontes bancárias, subsidiadas e mercado de capitais - sobre a alavancagem e a maturidade das dívidas das empresas nesses períodos.

Originalidade/valor: Crises estabelecem oportunidades para o estudo de fatores determinantes e seus impactos sobre as empresas. Não existem evidências empíricas sobre os impactos de crises sobre a estrutura de capital de empresas brasileiras levando em consideração a comparação entre as crises de 2002, 2008 e 2015, o que motivou o presente trabalho. Design/metodologia/abordagem: Foram feitas análises descritivas e estimadas regressões por dados em painel.

Resultados: Os resultados mostraram relação estatisticamente positiva entre crises financeiras e alavancagem das empresas, bem como sobre dívidas de curto e longo prazos. Com relação à alavancagem, recursos bancários, recursos dos mercados de capitais e subsidiados mostraram relação estatisticamente positiva com o nível de alavancagem das empresas apenas na crise de 2008. Considerando a maturidade das dívidas, a crise de 2002 foi um determinante importante para as decisões de endividamento de curto prazo das empresas, ante a participação predominante de recursos bancários naquele momento. As fontes de financiamento foram importantes na determinação do endividamento de longo prazo das empresas na crise de 2008. 


\section{PALAVRAS-CHAVE}

Estrutura de capital. Crises financeiras. Mercado de crédito. Fontes de financiamento. Alavancagem.

\section{$\int$ REFERENCES}

Akbar, S., Rehman, S. ur, \& Ormrod, P. (2013). The impact of recent financial shocks on the financing and investment policies of UK private firms. International Review of Financial Analysis, 26, 59-70. doi:10.1016/j.irfa. 2012. 05.004

Alves, P., \& Francisco, P. (2015). The impact of institutional environment on the capital structure of firms during recent financial crises. The Quarterly Review of Economics and Finance, 57, 129-146. doi:10.1016/j.qref.2014.12.001

Baker, M., \& Wurgler, J. (2002). Market timing and capital structure. The Journal of Finance, 57, 1-32. doi:10.1111/1540-6261.00414

Banco Nacional de Desenvolvimento Econômico e Social (2016). Relatório Anual de 2015. Recuperado de http://www.bndes.gov.br.

Blog do Ibre (2018). Comparação econômica: anos eleitorais de 2002 e 2018. Recuperado de https://blogdoibre.fgv.br

Booth, L., Aivazian, V., Demirguc-Kunt, A., \& Maksimovic, V. (2001). Capital structures in developing countries. The Journal of Finance, 56, 87-130. doi:10.1111/0022-1082.00320

Borges, W., Junior, T., Ambrozini, M. \& Rodrigues, L. (2018). O impacto da crise financeira internacional de 2008 sobre a estrutura de capital das empresas de países desenvolvidos e emergentes. Revista Contemporânea de Contabilidade, 15(34), 58-75. doi:10.5007/2175-8069.2018v15n34p58

Cardoso, V., \& Pinheiro, M. (2020). Influência da recessão e das variáveis macroeconômicas sobre a estrutura de capital setorial. Revista Contabilidade $\mathcal{E}$ Finanças, 31 (84), 392-408.

Carvalhal, A., \& Leal, R. (2013). The world financial crisis and the international financing of Brazilian companies. Brazilian Administration Review, 10(1), 18-39. doi:10.1590/S1807-76922012005000007

Faulkender, M., \& Petersen, M. (2006). Does the source of capital affect capital structure? The Review of Financial Studies, 19(1), 45-79. doi:10.1093/ rfs/hhj003 
Fávero, L. (2015). Análise de dados: Modelos de regressão com Excel ${ }^{\circledR}$, Stata ${ }^{\circledR}$ SPSS ${ }^{\circledR}$. Rio de Janeiro: Elsevier.

Fosberg, R. (2012). Capital structure and the financial crisis. Journal of Finance and Accountancy, 11, 1-10.

Frank, M., \& Goyal, V. (2009). Capital structure decisions: which factors are reliably important? Financial management, 38(1), 1-37. doi:10.1111/j. 1755-053X.2009.01026.x

Franzotti, T., \& Valle, M. (2020). Impacto de crises sobre investimentos e financiamentos de companhias brasileiras: Abordagem no contexto de restrições financeiras. Brazilian Business Review, 17(2), 233-252. doi:10.15728/ bbr.2020.17.2.6

Jensen, M., \& Meckling, W. (1976). Theory of the firm: Managerial behavior, agency costs and ownership structure. Journal of Financial Economics, 3(4), 305-360. doi:10.1016/0304-405X(76)90026-X

Kraus, A., \& Litzenberger, R. H. (1973). A state-preference model of optimal financial leverage. The Journal of Finance, 28(4), 911-922. doi:10.1111/j. 1540-6261.1973.tb01415.x

Lima, F. G., Assaf, A., Neto, P., Perera, L. C. J., \& Silva, A. C. da (2011). The impacts in the capital structure of Brazilian companies during periods of crisis. Journal of International Finance and Economics, 11, 154-160.

Modigliani, F., \& Miller, M. (1958). The cost of capital, corporation finance and the theory of investment. The American Economic Review, 48(3), 261-297.

Modigliani, F., \& Miller, M. (1963). Corporate income taxes and the cost of capital: A correction. The American Economic Review, 53 (3), 433-443.

Myers, S. (1984). The capital structure puzzle. The Journal of Finance, 39(3), 575-592. doi:10.1111/j.1540-6261.1984.tb03646.x

Myers, S. C., \& Majluf, N. S. (1984). Corporate financing and investment decisions when firms have information that investors do not have. Journal of Financial Economics, 13(2), 187-221. doi:10.1016/0304-405X(84)90023-0

Paula, L., Oreiro, J., \& Basilio, F. (2013). Estrutura do setor bancário e o ciclo recente de expansão do crédito: O papel dos bancos públicos federais. Nova Economia, 23 (3), 473-520. doi:10.1590/S0103-63512013000300001

Sant'Anna, A., Junior, B., Rodrigues, G., \& Araujo, P. (2009). Mercado de crédito no Brasil: Evolução recente e o papel do BNDES (2004-2008). Revista do BNDES, 16, 41-59.

Silva, E., Santos, J., Perobelli, F., \& Nakamura, W. (2016). Capital structure of Brazil, Russia, India and China by economic crisis. Revista de Administração Mackenzie, 17(3), 105-131. doi:10.1590/1678-69712016 
Tarantin, W., \& Valle, M. do (2015). Estrutura de capital: O papel das fontes de financiamento nas quais companhias abertas brasileiras se baseiam. Revista Contabilidade E Finanças-USP, 26(69), 331-344. doi:10.1590/1808057x201512130

\section{AUTHOR NOTES}

Tatiane D. A. Franzotti, master from the Ribeirão Preto School of Economics, Administration and Accounting (FEA-RP), University of São Paulo (USP); Vinícius M. Magnani, master from FEA-RP, USP; Marcelo A. Ambrozini, free-docency from FEA-RP, USP; Maurício R. Valle, freedocency from FEA-RP, USP.

Tatiane D. A. Franzotti is now accounting analyst and alumni at FEA-RP of USP; Vinícius M. Magnani is now controllership supervisor and professor at the Department of Accounting of Moura Lacerda University Center (CUML); Marcelo A. Ambrozini is now professor at FEA-RP of USP; Maurício R. Valle is now professor at FEA-RP of USP.

Correspondence concerning this article should be addressed to Tatiane D. A. Franzotti, Avenida Bandeirantes, 3900, Monte Alegre, Ribeirão Preto, São Paulo, Brazil, CEP 14040-905.

E-mail: tdfranzotti@gmail.com

\author{
EDITORIAL BOARD \\ Editor-in-chief \\ Gilberto Perez \\ Associated editor \\ Flávio Luiz de Moraes Barboza \\ Technical support \\ Vitória Batista Santos Silva
}

$\begin{array}{ll}\text { EDITORIAL PRODUCTION } & \\ \text { Publishing coordination } & \text { Layout designer } \\ \text { Jéssica Dametta } & \text { Emap } \\ \text { Editorial intern } & \text { Graphic designer } \\ \text { Paula Di Sessa Vavlis } & \text { Libro } \\ \text { Language editor } & \\ \text { Daniel de Almeida Leão } & \end{array}$

\section{EDITORIAL PRODUCTION}

Publishing coordination

Dametta

Layout designer

Graphic designer

Editorial intern

Language editor
Daniel de Almeida Leão 